\title{
Structural, optical and electrical characterizations of $\mathrm{ZnO} / \mathrm{PS}$
}

\author{
Zineb Yamlahi Alami ${ }^{1, a}$, Moez Salem ${ }^{2}$, Mounir Gaidi ${ }^{2,3}$ and Jamal El khamkhami ${ }^{1}$ \\ ${ }^{1}$ Condensed Matter Laboratory, Abdelmalek Essaadi University, Faculty of Sciences, M'hannech, Tetouan, Morocco \\ ${ }^{2}$ Photovoltaic Laboratory, Research and Technology Centre of Energy, Borj-Cedria Science and Technology Park, Hammam-Lif, Tunisia \\ ${ }^{3}$ Department of Applied Physics, University of Sharjah, Sharjah, United Arab Emirates
}

\begin{abstract}
This work reported on solar cell $\mathrm{ZnO} / \mathrm{PS}$ heterojunction fabricated from Zinc nitrate with molar concentrations $0.05 \mathrm{M}$ and $0.2 \mathrm{M}$ using spray pyrolysis technique, to study the effect of high and low molar concentration of $\mathrm{Zn}$ precursor on structural, optical and electrical properties. The structural analyse showed that the obtained thin films deposited on glass substrate were polycrystalline with a hexagonal wurtzite structure and preferentially oriented along the c-axis direction, while structural properties enhanced with higher morality $0.2 \mathrm{M}$. Roughness surface of $\mathrm{ZnO} / \mathrm{PS} \mathrm{HJ}$ increased widely with higher morality. Through I-V characteristics, the enhancement of electrical properties with higher molarity has been achieved. $I_{\mathrm{sc}}$ get augment from $23 \mathrm{~mA} / \mathrm{cm}^{2}$, to $27 \mathrm{~mA} / \mathrm{cm}^{2}$, and $\mathrm{V}_{\mathrm{oc}}$ from $551 \mathrm{mV}$ to $554 \mathrm{mV}$ when molarity has taken values $0.05 \mathrm{M}$ and $0.2 \mathrm{M}$ respectively. Ideality factor has influenced by molarity variance too. The impact of solar irradiance $\mathrm{G}$ and temperature $\mathrm{T}$ on solar cell fabricated from $0.2 \mathrm{M}$ molarity has been investigated. The current density increased from $13.53 \mathrm{~mA} / \mathrm{cm}^{2}$ to $27 \mathrm{~mA} / \mathrm{cm}^{2}$, the voltage from $525 \mathrm{mV}$ to $546 \mathrm{mV}$, and the efficiency from $5.2 \%$ to $10.9 \%$ when the solar irradiance have increased from 500 to $1000 \mathrm{~W} / \mathrm{m}^{2}$. The temperature also influences on the solar cell behaviours, especially the voltage is enhanced by temperature increasing.
\end{abstract}

\section{Introduction}

Several works have focused on studying the $\mathrm{n}-\mathrm{ZnO} / \mathrm{p}-\mathrm{Si}$ heterojunction behaviors because of its uses in different fields. For example, Chebil et al. [1] have deposited $\mathrm{ZnO}$ films on p-type crystalline silicon (p-Si) with [001] orientation, etched silicon and porous silicon by using sol gel spin coating method, they confirmed that the electrical properties of the $\mathrm{ZnO}$ layer deposition on porous are enhanced. Zebbar et al. [2] have prepared heterojunction structures of $\mathrm{n}-\mathrm{ZnO} / \mathrm{p}-\mathrm{Si}$ by ultrasonic spray method, they obtained improved structural and optical properties as temperature of substrate increases. The ideality factor of obtained heterojunction was larger than 2 , the activation energy of saturation current was about $0.14 \mathrm{eV}$ and the junction built-in potential deduced from $\mathrm{C}-\mathrm{V}$ measurements was equal to $1.14 \mathrm{~V}$ at room temperature.

In this work, the effect of both molar concentrations $0.05 \mathrm{M}$ and $0.2 \mathrm{M}$ on structural and morphological properties of $\mathrm{ZnO}$ thin films nanoparticle deposited on glass substrate are studied. A layer of $\mathrm{n}-\mathrm{ZnO}$ fabricated with both molarities, $0.05 \mathrm{M}$ and $0.2 \mathrm{M}$, and allowed to grow on porous silicon substrate to fabricate a heterojunction solar cell is considered. The effect of deposing a layer of $\mathrm{ZnO}$ thin film nanoparticle with lower and higher molar concentration on I-V characteristics is studied. Then, factors ideality are extracted from I-V curves. Due to its high optical and

${ }^{\mathrm{a}}$ Corresponding author a.yamlahizineb@gmail.com electrical properties, the $\mathrm{n}-\mathrm{ZnO} / \mathrm{p}$-Si fabricated by higher molar concentration $0.2 \mathrm{M}$ is simulated using Matlab software. The objective is to study the impact of solar irradiance $G$ between $500 \mathrm{w} / \mathrm{m}^{2}$ and $1000 \mathrm{w} / \mathrm{m}^{2}$ and cell temperature between $25^{\circ} \mathrm{C}$ and $35^{\circ} \mathrm{C}$ on behavior of this device.

\section{Experimental work}

Experiments were carried out on p-type, boron-doped multi-crystalline silicon substrate with a thickness of $350 \mu \mathrm{m}$ and a resistivity of $0.5-2 \Omega \mathrm{cm}$ [3]. $\mathrm{ZnO}$ films are prepared by the spray pyrolysis method using solution containing zinc nitrate $\left[\mathrm{Zn}\left(\mathrm{NO}_{3}\right)_{2}, 2 \mathrm{H}_{2} \mathrm{O}\right]$ in $25 \mathrm{ml}$ of deionized water. The concentration of the precursor solution was fixed at one of the values $0.05 \mathrm{M}$ and $0.2 M$. The spray rate of the $\left[\mathrm{Zn}\left(\mathrm{NO}_{3}\right)_{2}, 2 \mathrm{H}_{2} \mathrm{O}\right]$ solution was kept constant at $2 \mathrm{ml} / \mathrm{min}$ onto a preheated porous silicon at $500^{\circ} \mathrm{C}$ temperature for $10 \mathrm{~min}$.

The crystallographic structure of the films was studied by X-ray diffraction XRD technique. The surface morphology was characterized via atomic force microscopy (AFM). The reflectivity spectra of the different treated mc-Si surface was measured using a LAMBDA 950UV/Vis/NIR spectrophotometer equipped with an integrating sphere. The configuration for $\mathrm{I}-\mathrm{V}$ measurements was performed using two-electrodes, which were applied on front and back extremities of the sample using $\mathrm{Au}$ and $\mathrm{Al}$ contacts, respectively. Current voltage measurements were performed using a computer 
controlled set up comprising a Keithley 220 current source and an Agelint 34401A multimeter under 1.5 AM illumination solar spectrum $\left(100 \mathrm{mW/} \mathrm{cm}^{2}\right)$.

\section{Results and discussion}

\subsection{Structural studies}

Figure1 shows the XRD of $\mathrm{ZnO}$ films prepared by $0.05 \mathrm{M}$ and $0.2 \mathrm{M}$. Both these molarities exhibited an orientation along c-axis (002) perpendicular to the substrate surface, which indicates a hexagonal Wurtzite structure. However, the intensity of (002) plan has increased and $2 \theta$ position has shifted, taking $34.40^{\circ}$ then $34.51^{\circ}$ values respectively. For the $\mathrm{ZnO}$ powder, the peak position is $2 \theta=34.42^{\circ}$, the shift of the (002) peak position from its powder value are mainly associated with strain produced within the film [4].

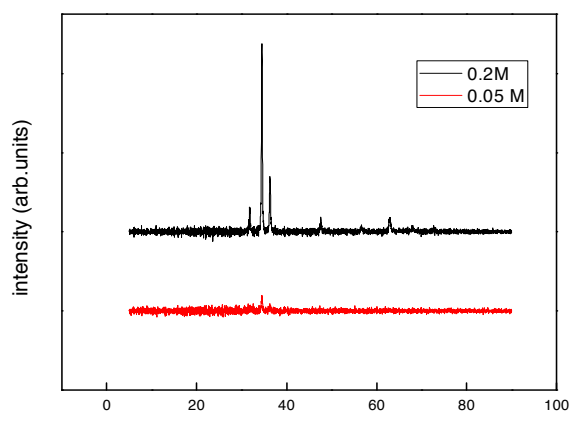

Figure 1. X-ray diffraction spectra of $\mathrm{ZnO}$ thin films deposited on glass substrate with different molar concentrations.

To have a clue about the crystallinity of the films, the crystallite size is calculated by Scherer formula:

$$
\mathrm{D}=\frac{0.9 \lambda}{\beta \sin \theta}
$$

where $\beta$ is the full width half maximum of the peak (FWHM), $\lambda$ is the $\mathrm{X}$-ray wavelength $\left(1.5406 \AA\right.$ for $\left.\mathrm{CuK}_{\alpha}\right)$ and $\theta$ is the Bragg's angle.

The crystallite size increased from $10 \mathrm{~nm}$ to $33 \mathrm{~nm}$ for $0.05 M$ and $0.2 M$ respectively. We have calculated the dislocation density $\delta$ of the films by the formula [5]:

$$
\delta=\frac{1}{D^{2}}
$$

with $D$ is the average grain size.

The dislocation density is defined as the length of dislocation lines per unit volume of the crystal. This parameter is taking $1 \times 10^{-2} \mathrm{~nm}^{-2}$ and $9.4 \times 10^{-4} \mathrm{~nm}^{-2}$ values for $0.05 \mathrm{M}$ and $0.2 \mathrm{M}$ respectively. Larger $D$ and smaller $\delta$ values mean better crystallization of the films which indicates that the higher molar concentration reduces the crystal lattice imperfections.
To estimate the stress in the plane of the substrate surface, the c-axis strain $\mathcal{E}_{z z}$ values has been calculated using the following equation [6]:

$$
\varepsilon_{z z}=\frac{c-c_{0}}{c_{0}} \times 100
$$

where $c$ is the lattice parameter of the strained films calculated from the X-ray diffraction data and $c_{0}$ is the lattice parameter of bulk $\mathrm{ZnO}$.

For $0.05 M$ this value is equal +0.1 , however it is equal -0.19 for $0.2 M, \varepsilon_{z z}>0$ suggesting that the film is subjected to tensile stress in the plane of the substrate surface with $0.05 M$, and to compressive stress with $0.2 \mathrm{M}$.

In thin films, strains originate mainly from the mismatch between the polycrystalline film and the amorphous substrate and/or from the difference in the thermal expansion coefficients of the film and the substrate [7].

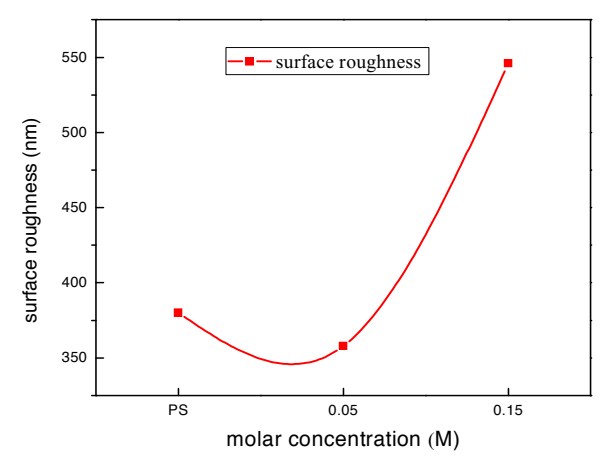

Figure 2. Surface roughness of $\mathrm{ZnO} / \mathrm{PS}$ films as a function of molar concentration.

\subsection{Morphogical studies}

As it shown in Figure 2, the surface roughness of $\mathrm{ZnO} / \mathrm{PS}$ films with $0.05 \mathrm{M}$ is equal to $358 \mathrm{~nm}$, however, it is equal to $546 \mathrm{~nm}$ when the molar concentration is $0.2 \mathrm{M}$. This result is due to the increase of size crystal, which leads to reduce the grain boundary, so the path of light stretches [8].

\subsection{Optical studies}

Figure 3 shows the optical reflectance spectra $R(\%)$ of the $\mathrm{ZnO} / \mathrm{PS}$ heterojunction of two samples fabricated by different molar concentration of $\mathrm{Zn}$ precursors, $0.05 \mathrm{M}$ and $0.2 \mathrm{M}$ and the Porous silicon film without treatment. The average reflectance of the porous silicon thin film without treatment is $13 \%$. This value has increased to $17 \%$ when a layer of $0.05 \mathrm{M}$ is deposited, but it is returned to decrease to $10 \%$ when layer of $0.2 \mathrm{M}$ is deposited. The reduction of the reflectivity is due to roughly ordered structure originating from pores formation. Low reflectance improves the efficiency solar cell because of increase in photons absorption. 


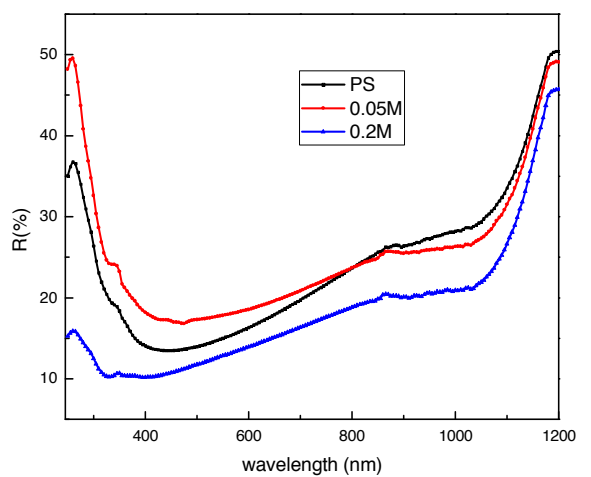

Figure 3. Total reflectivity of $\mathrm{ZnO} / \mathrm{PS}$.

\subsection{Electrical studies}

The I-V curve for $\mathrm{ZnO} / \mathrm{PS}$ nanoparticle thin film heterojunction device was measured. The obtained results are depicted in Figure 4. The nonlinear characteristics of the device indicate the typical diode behavior of the device to perform the current-voltage analysis of the diode. This is conforming to the equation of single junction solar cell, double-diode equivalent circuit [9]:

$$
I=I_{p h}-I_{s 1} \exp \left(\frac{q\left(V+I R_{s}\right)}{K T n}-1\right)-I_{s 2} \exp \left(\frac{q\left(V+I R_{s}\right)}{K T m}-1\right)-\frac{V+I R_{s}}{R_{s h}}
$$

where $I_{p h}$ is light-generated current or photocurrent, $q$ the electron charge $\left(=1,6 \cdot 10^{-19} \mathrm{C}\right), \mathrm{K}$ is the Boltzmann's constant $\left(=1.38 .10^{-23} \mathrm{~J} / K\right), \quad T$ is the cell's operating temperature in Kelvin $(K), n$ is the ideality factor of the first diode and $m$ is the ideality factor of the second diode, $R_{s h}$ is the shunt resistance, and $R_{S}$ is the series resistance, The current $I_{S 1}$ and $I_{S 2}$ are called the diode saturation dark current and it depends on the reverse saturation current.

The ideality factors $n$ and $m$ can be calculated from the slope of the straight line region of the forward bias $\ln (I)-V$ plot, the equation which gives $n$ or $m$ can be written as follows [2] :

$$
n=\frac{q}{K T} \times \frac{d V}{d \ln (I)}
$$

Table 1 illustrates the variation of the ideality factors $n$ and $m$ before and after deposing $\mathrm{ZnO}$ layer with low and high molar concentration.

After carrying out the structural characterization of the as-grown $\mathrm{ZnO}$ thin film with 0.05 and 0.2 molar concentration, it can be stated that the higher molar concentratmion $0.2 \mathrm{M}$ enhances structural properties of the $\mathrm{ZnO}$ thin film deposited on glass substrate. Through the roughness surface and reflectance studies of $\mathrm{ZnO} / \mathrm{PS}$ heterojunction film, the superior optical characteristics of $\mathrm{ZnO} / \mathrm{PS}$ with higher molar concentration are obvious and the electrical studies demonstrated that the efficiency of this solar cell is improved.

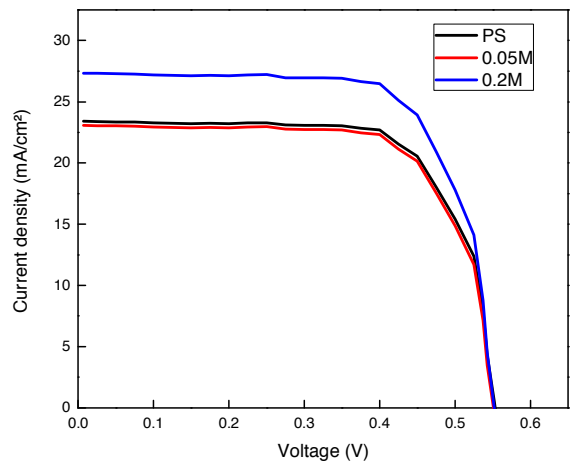

Figure 4. $\mathrm{I}-\mathrm{V}$ characterization of $\mathrm{ZnO} / \mathrm{PS}$ films before and after treatment.

By using equations (4) to (9) given in reference [10], in which series number of cell, $N S=54$, cell temperature, $T=30^{\circ} \mathrm{C}$, solar irradiance $G=1000 \mathrm{~W} / \mathrm{cm}^{2}$, series resistance, $R_{s}=0.221$ and shunt resistance is $R_{s h}=4150$, we have succeed to simulate I-V curves of solar cell fabricated with $0.2 \mathrm{M}$ similar to those obtained in experiment, as it's shown in Figure 5.

Table1. Ideality factors of different solar cells.

\begin{tabular}{|c|c|c|c|}
\hline Sample & $\begin{array}{c}\text { Porous } \\
\text { silicon }\end{array}$ & $\mathbf{0 . 0 5 M}$ & $\mathbf{0 . 2 M}$ \\
\hline Factor ideality n & 7.63 & 6.6 & 5.5 \\
\hline Factor ideality $\mathbf{m}$ & $\#$ & 17.7 & 20 \\
\hline
\end{tabular}

$$
\begin{gathered}
V_{O C}=\frac{K T}{q} \ln \left(\frac{I_{p h}}{I_{s}}\right) \\
I_{r 2}=\frac{I_{p h}}{\exp \left(\frac{q V}{K T_{c} n}-1\right)} \\
I_{s 1}=I_{r s 1}\left(\frac{T_{c}}{T_{c r e f}}\right)^{3} \exp \left(\frac{q E_{g 1}\left(\frac{1}{T_{c r e f}}-\frac{1}{T_{c}}\right)}{K n}\right) \\
I_{s 2}=I_{r s 2}\left(\frac{T_{c}}{T_{c r e f}}\right)^{\frac{3}{2}} \exp \left(\frac{q E_{g 2}\left(\frac{1}{T_{c r e f}}-\frac{1}{T_{c}}\right)}{K m}\right)
\end{gathered}
$$

In order to understand the behaviors of $\mathrm{ZnO} / \mathrm{PS}$ fabricated with $0.2 \mathrm{M}$, we have studied the impact of several parameters, by varying the solar irradiance between 500 and $1000 \mathrm{~W} / \mathrm{m}^{2}$ and the temperature between $25^{\circ} \mathrm{C}$ and $35^{\circ} \mathrm{C}$. As it is shown in Figure 6 , the current density is widely influenced by solar irradiance increasing. When the solar irradiance has increased from 500 to $1000 \mathrm{~W} / \mathrm{m}^{2}$, the density current increased from $13.53 \mathrm{~mA} / \mathrm{cm}^{2}$ to $27 \mathrm{~mA} / \mathrm{cm}^{2}$, whereas the voltage has increased from $525 \mathrm{mV}$ to $546 \mathrm{mV}$, and the efficiency from $5.1 \%$ to $10.4 \%$. 
Therefore, when the device has absorbed more photons, it can be able to generate more electron-pairs in the depletion semiconductor layer. This indicates that the light illumination increases the generation of electronhole pairs. Illuminating the solar cell, electrons in the valence band of the $\mathrm{ZnO}$ absorb energy, and they are able to jump to the conduction layer.

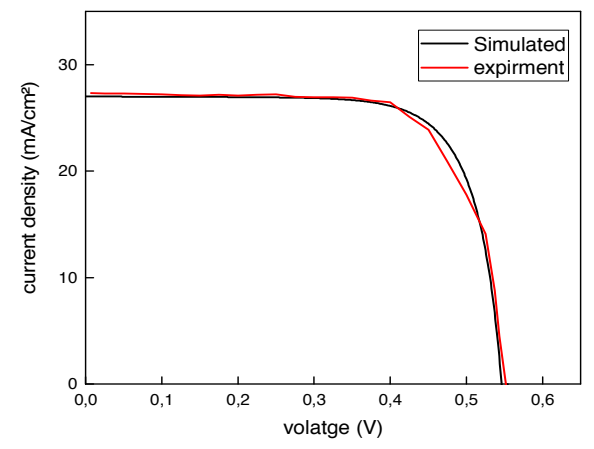

Figure 5. I-V curves of $0.2 M$-solar cell.

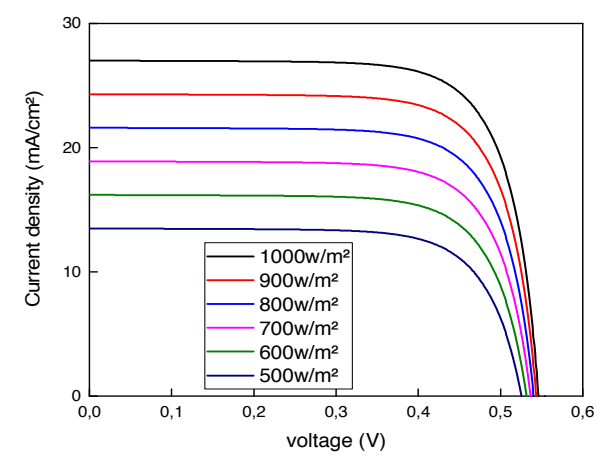

Figure 6. I-V curves of $\mathrm{ZnO} / \mathrm{PS}$ under different solar irradiations

The value of voltage is influenced by varying the temperature of PV cell, however the current density is unchanged. As can be seen in Figure 7, voltage has decreased when the temperature increases. This result might be explained by the decrease in the band of semiconductor because of the increase of the energy of the electrons in the material.

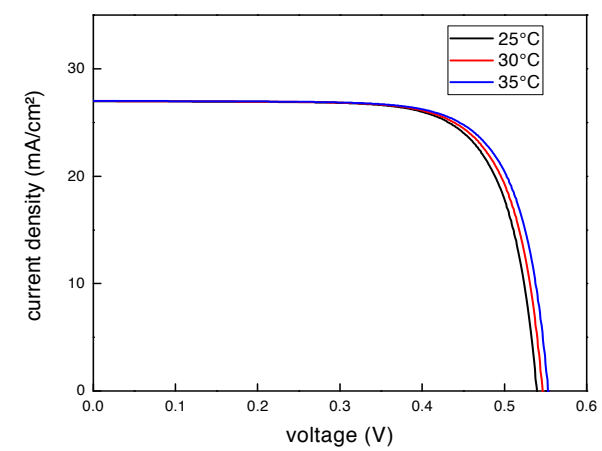

Figure 7. I-V curves of solar cell with various temperatures.

\section{Conclusions}

The heterojunction solar cell of $\mathrm{ZnO} / \mathrm{PS}$ thin films was successfully fabricated by varying molar concentration of precursor. $\mathrm{ZnO} / \mathrm{PS}$ fabricated from $0.2 \mathrm{M}$ demonstrated the best proprieties structural, optical and electrical. Its surface roughness was $546 \mathrm{~nm}$, reflectivity was $10 \%$, current density $27 \mathrm{~mA} / \mathrm{cm}^{2}$, voltage $554 \mathrm{mV}$ and its efficiency was $10.7 \%$. The impact of solar irradiance on this cell was studied; the current density and voltage increased largely when the solar irradiance has increased. However, when the temperature has increased the density of current was unaffected and the voltage was decreased.

\section{References}

1. W. Chebil, A. Fouzri, A. Fargi, B. Azeza, Z. Zaaboub, V. Sallet,Mater. Res. Bull., 70 (2015)

2. N. Zebbar, Y. Kheireddine, K. Mokeddem, A. Hafdallah, M. Kechouane, M.S. Aida, Mater. Sci. Semicond. Process., 14 (2011)

3. M. Salem, Z.Y. Alami, B. Bessais, A. Chahboun, M. Gaidi, , J. Nanoparticle Res., 17 (2015)

4. V. Gupta, A. Mansingh, J. Appl. Phys., 80 (1996)

5. L. Yang, B. Duponchel, R. Cousin, C. Gennequin, G. Leroy, J. Gest, J.-C. Carru, Thin Solid Film, 520 (2012)

6. A.C. Rastogi, S.B. Desu, P. Bhattacharya, R.S. Katiyar, 13 (2004)

7. R. Swapna, M. Ashok, G. Muralidharan, M.C. Santhosh Kumara, Journal of Analytical and Applied Pyrolysis, 102 (2013)

8. M.-S. Kim, B.-G. Kim, J. Kim, ACS Appl. Mater. Interfaces, 1 (2009)

9. M. Catelani, L. Ciani, M.K. Kazimierczuk, A. Reatti, Measurement, 88 (2016)

10. S.K. Cheung, N.W. Cheung, Appl. Phys. Lett., 49 (1986) 